\title{
Bacterial Meningeal Score [BMS] Sebagai Indikator Diagnosis Meningitis Bakterialis di RSUP Dr. Sardjito Yogyakarta
}

Arydina, Elisabeth S Herini, Agung Triono

Bagian Ilmu Kesehatan Anak Fakultas Kedokteran Universitas Gadjah Mada/RSUP Dr. Sardjito, Yogyakarta

Latar belakang. Meningitis bakterialis merupakan salah satu penyebab morbiditas dan mortalitas yang penting pada anak. Anak dengan meningitis biasa datang ke rumah sakit dan mendapat antibiotik intrakranial tanpa menunggu hasil kultur. Hal ini dilakukan karena membedakan meningitis bakterialis dan meningitis bukan bakteri pada awal perjalanan penyakit terkadang sulit. Beberapa indikator dapat digunakan untuk membedakan hal itu. Salah satunya adalah bacterial meningeal score (BMS), terdiri dari pengecatan gram cairan serebrospinal positif, protein cairan serebrospinal $\geq 80 \mathrm{mg} / \mathrm{dL}$, neutrofil darah tepi $\geq 10.000 \mathrm{sel} / \mathrm{mm}^{3}$, riwayat kejang, neutrofil absolut cairan serebrospinal $\geq 1000 \mathrm{sel} / \mathrm{mm}^{3}$.

Tujuan. Mengetahui apakah bacterial meningeal score merupakan indikator yang baik untuk menegakkan diagnosis meningitis bakterialis akut pada bayi dan anak

Metode. Uji diagnostik pada anak usia >1 bulan-18 tahun, yang dicurigai sebagai meningitis berdasarkan kriteria WHO, mulai Februari 2011 sampai dengan April 2011. Diagnosis meningitis bakterialis ditegakkan apabila hasil kultur ditemukan bakteri.

Hasil. Di antara 31 anak subjek penelitian, 16 laki-laki. Semua datang dengan demam, kejang (29/31), penurunan kesadaran (15/31), dan tanda meningeal (17/31). Pengecatan gram positif pada 9/31 sampel dan kultur positif 12/31 sampel. Hasil analisis statistik didapatkan sensitivitas BMS 83,3\%, spesifisitas 89,5\%, nilai praduga negatif $83,3 \%$, nilai praduga positif $89,5 \%$, likelihood ratio positif 7,92 , dan likelihood ratio negatif 0,186. Bakteri yang tumbuh dari hasil kultur adalah P. aerogenosa, S.epidermidis and Paracoccus $s p$, Bacillus. Sp dan Enterococcus sp.

Kesimpulan. Bacterial meningeal score merupakan indikator yang baik untuk menilai meningitis bakteri pada bayi dan anak karena memiliki sensitivitas, spesifisitas, nilai praduga negatif, nilai praduga positif, likelihood ratio positif dan likelihood ratio negatif yang tinggi. Sari Pediatri 2014;15(5):274-80.

Kata kunci: bacterial meningitis score, meningitis, anak

Alamat korespondensi:

Dr. Arydina. Ilmu kesehatan Anak FK UGM/RSUP Dr. Sardjito, Jl. Kesehatan no.1 Yogyakarta. Telpon: 08156508364. E-mail: arydinateguh@ yahoo.co.id.

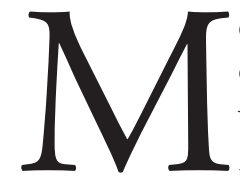

eningitis adalah radang pada selaput otak yang dapat disebabkan oleh bakteri, virus, parasit, jamur, dan keadaan non infeksi seperti neoplasma. ${ }^{1}$ Meningitis 
akut pada anak umumnya merupakan meningitis aseptik dan tidak memerlukan pengobatan spesifik. Namun, 4\%-6\% kasus meningitis akut merupakan meningitis bakteri. ${ }^{2}$ Karena sulit membedakan antara meningitis bakterialis dan meningitis aseptik pada awal perjalanan penyakitnya, maka setiap anak dengan gejala klinis meningitis akut, diberikan antibiotik sampai kultur tersedia, kira-kira 48 sampai 72 jam kemudian. Akibatnya banyak didapatkan hospitalisasi dan pengunaan antibiotik pada anak dengan meningitis aseptik yang dikaitkan dengan kematian dan mempunyai dampak ekonomi. ${ }^{2,3}$ Bacterial meningeal score adalah suatu sistem skoring yang dapat digunakan untuk membedakan meningitis bakteri dengan meningitis aseptik, dan memiliki nilai prediksi negatif $100 \%$ dan sensitivitas $100 \%{ }^{4}$

Bacterial meningeal score terdiri dari pengecatan gram cairan serebrospinal positif, protein cairan serebrospinal $\geq 80 \mathrm{mg} / \mathrm{dL}$, neutrofil darah tepi $\geq 10.000 \mathrm{sel} / \mathrm{mm}^{3}$, riwayat kejang, neutrofil absolut cairan serebrospinal $\geq 1000 \mathrm{sel} / \mathrm{mm}^{3}$. ${ }^{2,5,6}$ Masingmasing skor memiliki nilai tersendiri. (Tabel 1)

Bacterial meningeal score telah diteliti pada beberapa negara, tetapi belum pernah di teliti di Indonesia. Kultur sebagai baku emas pada meningitis dari beberapa penelitian hanya positif 6\%-50\% kasus meningitis. ${ }^{7}$ Sensitivitas kultur menurun 30\% apabila telah diberikan antibiotik sebelum lumbal pungsi dilakukan. ${ }^{8}$ Bacterial meningeal score sebenarnya dapat diterapkan di fasilitas kesehatan yang terbatas, misalnya di rumah sakit daerah atau Puskesmas yang belum memungkinkan dilakukan kultur.

Penelitian ini bertujuan untuk mengetahui apakah BMS merupakan indikator yang baik untuk menegakkan diagnosis meningitis bakterial akut pada bayi dan anak.

\section{Metode}

Penelitian uji diagnosis dengan populasi pasien yang dirawat di bangsal anak dan Pediatric Intensive Care Unit (PICU) RSUP Dr. Sardjito mulai 1 Februari 2011 sampai dengan 30 April 2011. Diagnosis saat awal masuk adalah curiga meningitis berdasarkan WHO. Sampel penelitian diambil dengan consecutive sampling. Kriteria inklusi adalah anak umur $\geq 1$ bulan -18 tahun dengan kecurigaan meningitis akut pada saat mulai dirawat. Kesediaan mengikuti penelitian dengan menandatangani surat persetujuan. Kriteria eksklusi adalah pasien yang telah mendapat terapi antibiotik dosis intrakranial 72 jam sebelum pungsi lumbal, data tidak lengkap dan pungsi lumbal yang gagal. Besar sampel dihitung berdasarkan uji diagnostik dengan sensitivitas yang ditetapkan berdasarkan penelitian sebelumnya (99\%), tingkat kesahihan 95\% dan nilai penyimpangan yang masih dapat diterima 20\%, didapatkan jumlah sampel minimal adalah 31 sampel.

Parameter utama yang akan dinilai adalah $B M S$ pada pasien dengan curiga meningitis akut berdasarkan kriteria WHO, yaitu adanya riwayat demam, muntah, tidak bisa minum atau menyusu, sakit kepala atau nyeri di belakang leher, penurunan kesadaran, kejang, gelisah, dan cedera kepala yang baru dialami. Pemeriksaan fisik berdasarkan tanda rangsang meningeal, kejang, letargis, gelisah, ubun-ubun cembung, ruam, dan trauma kepala yang menunjukkan kemungkinan fraktur tulang tengkorak yang baru terjadi. Skor BMS berkisar antara 0-6. Pasien berdasarkan BMS dikelompokkan menjadi dua kelompok, yaitu $B M S$ $<2$ yang artinya pasien mempunyai risiko rendah untuk menderita meningitis bakteri dan $B M S \geq 2$ yang artinya pasien mempunyai risiko tinggi untuk menderita meningitis bakteri.

Tabel 1. Bacterial meningeal score

\begin{tabular}{lcc}
\hline Prediktor & \multicolumn{2}{c}{ Skor } \\
\cline { 2 - 3 } & Ada & Tidak ada \\
\hline Pengecatan gram positif & 2 & 0 \\
Protein cairan serebrospinal $\geq 80 \mathrm{mg} / \mathrm{dL}$ & 1 & 0 \\
Neutrofil darah tepi $\geq 10.000 \mathrm{sel} / \mathrm{mm}^{3}$ & 1 & 0 \\
Riwayat kejang & 1 & 0 \\
Neutrofil cairan serebrospinal $\geq 1000 \mathrm{sel} / \mathrm{mm}^{3}$ & 1 & 0 \\
\hline
\end{tabular}

Sari Pediatri, Vol. 15, No. 5, Februari 2014 
Analisis liquor cerebrospinal (LCS) dilakukan di laboratorium Patologi Klinik RSUP Dr. Sardjito dengan Advia 120. Pengecatan gram dan kultur LCS dilakukan di Laboratorium Mikrobiologi Universitas Gadjah Mada, Yogyakarta. Medium yang digunakan adalah agar coklat (darah kambing 5\%), agar darah (kambing dan human). Media transport yang digunakan adalah stuart dan thloglycolat broth. Pada biakan ini tidak dilakukan kultur untuk virus. Meningitis bakteri dinyatakan apabila kultur LCS terdapat bakteri yang tumbuh dan bukan meningitis bakteri apabila kultur LCS tidak ditemukan adanya bakteri. Tidak dilakukan uji kappa untuk kesesuaian pengukuran dan cara pengambilan sampel. Data yang didapatkan adalah data berskala nominal. Dilakukan uji diagnosis dengan menghitung sensitivitas dan spesifisitas, nilai duga positif, nilai duga negatif, likelihood ratio positif dan likelihood ratio negatif terhadap BMS dan beberapa indikator meningitis bakteri lainnya.

\section{Hasil}

Selama kurun waktu 4 bulan diperoleh 39 sampel penelitian dengan kriteria masuk curiga meningitis. Terdapat 8 anak yang tidak diikutsertakan karena 4 telah mendapat antibiotik dosis intrakranial sebelum pungsi lumbal, 2 data hilang, dan 2 tidak setuju untuk mengikuti penelitian (Gambar 1).

Meningitis bakteri lebih banyak terjadi pada anak usia 1-5 tahun dengan perbandingan laki-laki lebih banyak dibandingkan perempuan. Limabelas dari 31 subjek datang dengan penurunan kesadaran dan rangsang meningeal positif. Hasil kultur positif $12 / 31$ sedangkan pengecatan gram positif $9 / 31$ sampel (Tabel 2).

Dilakukan analisis bivariat terhadap indikator pada meningitis bakteri dengan menggunakan chi square. Indikator dinyatakan secara signifikan bermakna terhadap meningitis bakteri apabila $\mathrm{p}<0,05$. Beberapa indikator meningitis bermakna adalah kesadaran, neutrofil LCS, protein LCS, glukosa LCS, pengecatan gram, dan BMS dengan nilai $\mathrm{p}<0,05$. Hasil analisis tertera pada Tabel 3 .

Hasil analisis statistik menunjukkan BMS memiliki nilai sensitivitas yang paling tinggi jika dibandingkan dengan indikator lainnya. Sensitivitas BMS didapatkan $83,3 \%$, spesifisitas $89,5 \%$, nilai
Tabel 2. Karakteristik sampel penelitian

\begin{tabular}{|c|c|}
\hline Variabel & $\mathrm{n}$ \\
\hline \multicolumn{2}{|l|}{ Jenis kelamin } \\
\hline Laki-laki & 16 \\
\hline Perempuan & 15 \\
\hline \multicolumn{2}{|l|}{ Usia (tahun) } \\
\hline$<1$ & 12 \\
\hline $1-5$ & 17 \\
\hline$>5$ & 2 \\
\hline Demam & 31 \\
\hline \multicolumn{2}{|l|}{ Kesadaran } \\
\hline Kompos mentis & 16 \\
\hline Penurunan kesadaran & 15 \\
\hline \multicolumn{2}{|c|}{ Tanda rangsang meningeal } \\
\hline Ada & 17 \\
\hline Tidak & 14 \\
\hline \multicolumn{2}{|l|}{ Kejang } \\
\hline Ada & 29 \\
\hline Tidak & 2 \\
\hline \multicolumn{2}{|c|}{ Neutrofil darah tepi (/ mm3) } \\
\hline$<10.000$ & 26 \\
\hline$\geq 10.000$ & 5 \\
\hline \multicolumn{2}{|l|}{ Protein LCS (mg/dL) } \\
\hline$<80$ & 24 \\
\hline$\geq 80$ & 7 \\
\hline \multicolumn{2}{|l|}{ Neutrofil LCS (/ mm3) } \\
\hline$<1000$ & 27 \\
\hline$\geq 1000$ & 4 \\
\hline \multicolumn{2}{|l|}{ Pengecatan gram } \\
\hline Positif & 9 \\
\hline Negatif & 21 \\
\hline \multicolumn{2}{|l|}{ Kultur } \\
\hline Positif & 12 \\
\hline Negatif & 19 \\
\hline
\end{tabular}

praduga negatif $83,3 \%$, nilai praduga positif $89,5 \%$, likelihood ratio positif 7,92, dan likelihood ratio negatif 0,186 . Namun, untuk spesifisitas neutrofil LCS $>1000 \mathrm{sel} / \mathrm{mm}^{3}$ dan pengecatan gram memiliki nilai yang lebih baik dibandingkan BMS. Hasil uji diagnosis beberapa indikator pada penelitian tertera pada Tabel 4.

Bakteri terbanyak yang tumbuh dari kultur adalah P.aerogenosa selain bakteri lain, yaitu S. epidermidis, Bacillus sp, Enterococcus sp dan Paracoccus sp. Hasil kultur LCS tertera pada Tabel 5. 
Tabel 3. Analisis bivariat indikator meningitis bakteri

\begin{tabular}{|c|c|c|c|}
\hline Variabel & Meningitis bakteri & Bukan meningitis bakteri & $\mathrm{p}$ \\
\hline Jenis kelamin & & & 0,018 \\
\hline Laki-laki & 9 & 6 & \\
\hline Perempuan & 3 & 13 & \\
\hline Usia (tahun) & & & 0,147 \\
\hline$<1$ & 7 & 5 & \\
\hline $1-5$ & 5 & 12 & \\
\hline$>5$ & 0 & 2 & \\
\hline Demam & 12 & 19 & - \\
\hline Kesadaran & & & 0,038 \\
\hline Kompos mentis & 1 & 12 & \\
\hline Penurunan kesadaran & 4 & 14 & \\
\hline Tanda rangsang meningeal & & & 0,293 \\
\hline Ada & 8 & 9 & \\
\hline Tidak & 4 & 10 & \\
\hline Kejang & & & 0,735 \\
\hline Ada & 11 & 18 & \\
\hline Tidak & 1 & 1 & \\
\hline Neutrofil darah tepi (/ mm3) & & & 0,348 \\
\hline$<10.000$ & 11 & 15 & \\
\hline$\geq 10.000$ & 1 & 4 & \\
\hline Protein LCS (mg/dL) & & & 0,043 \\
\hline$<80$ & 7 & 17 & \\
\hline$\geq 80$ & 5 & 2 & \\
\hline Neutrofil LCS (/ mm3) & & & 0,007 \\
\hline$<1000$ & 8 & 19 & 0,000 \\
\hline$\geq 1000$ & 4 & 0 & \\
\hline Glukosa LCS (mg/dL) & & & 0,043 \\
\hline$\leq 40$ & 5 & 2 & \\
\hline$>40$ & 7 & 17 & \\
\hline Pengecatan gram & & & 0,000 \\
\hline Positif & 9 & 0 & \\
\hline Negatif & 3 & 13 & \\
\hline BMS & & & 0,000 \\
\hline$<2$ & 2 & 17 & \\
\hline$\geq 2$ & 10 & 2 & \\
\hline
\end{tabular}

Tabel 4. Uji diagnosis beberapa indikator pada meningitis bakteri

\begin{tabular}{|c|c|c|c|c|c|c|}
\hline Indikator & $\begin{array}{c}\text { Sensitivitas } \\
(95 \% \text { IK) }\end{array}$ & $\begin{array}{c}\text { Spesifisitas } \\
(95 \% \mathrm{IK})\end{array}$ & $\begin{array}{l}\text { Nilai duga } \\
\text { positif }\end{array}$ & $\begin{array}{c}\text { Nilai duga } \\
\text { negatif }\end{array}$ & $\begin{array}{c}\text { Likelihood } \\
\text { positif }\end{array}$ & $\begin{array}{c}\text { Likelihood } \\
\text { negatif }\end{array}$ \\
\hline Penurunan kesadaran & $80(37,6 ; 96,4)$ & $46,2(28,8 ; 64,5)$ & 22,2 & 92,3 & 1,486 & 0,433 \\
\hline Glukosa LCS & $41,7(19,3 ; 68)$ & $89,5(68,6 ; 97,1)$ & 71,4 & 70,8 & 3,9 & 65,2 \\
\hline Protein LCS & $41,7(19,3 ; 68)$ & $89,5(68,6 ; 97,1)$ & 71,4 & 70,8 & 3,9 & 65,2 \\
\hline Neutrofil LCS $\geq 1000 \mathrm{sel} / \mathrm{mm}^{3}$ & $34,6(15,1 ; 61,1)$ & $97,5(80 ; 99,7)$ & 90 & 69,6 & 13,8 & 0,671 \\
\hline Pengecatan gram & $73,1(46 ; 89,6)$ & $97,5(73,2 ; 99,6)$ & 95 & 84,8 & 29,24 & 27,6 \\
\hline BMS $\geq 2$ & $83,3(55,2 ; 95,3)$ & $89,5(68,6 ; 97,1)$ & 83,3 & 89,5 & 7,9 & 0,186 \\
\hline
\end{tabular}


Tabel 5. Hasil kultur dan pengecatan gram

\begin{tabular}{llc}
\hline No & Pengecatan gram & Kultur \\
\hline 1 & Kokus gram (+) & S. epidermidis \\
2 & Tidak ditemukan bakteri & Bacillus. Sp \\
3 & Kokus gram (+) dan gram (-) & Enterococcus sp \\
4 & Diplokokus gram (-), batang gram (-), diplokokus gram (+) & P. aeroginosa \\
5 & Batang gram (-), diplokokus gram (+) & P. aeruginosa \\
6 & Tidak ditemukan bakteri & S.epidermidis \\
7 & Kokus gram (+) & S.epidermidis \\
8 & Diplokokus gram (-), batang gram (-), diplokokus gram (+) & P.aeruginosa \\
9 & O-shape & Paracoccus sp \\
10 & Tidak ditemukan bakteri & S. epidermidis \\
11 & Diplokokus gram (+), batang gram (-) & P.aeruginosa \\
12 & Kokus gram (+) dan gram (-) & P. aeruginosa \\
\hline
\end{tabular}

\section{Pembahasan}

Salah satu faktor pejamu yang berpengaruh dalam terjadinya meningitis bakteri adalah jenis kelamin lakilaki. ${ }^{10}$ Penelitian di Rural mozambique, ${ }^{11}$ ditemukan kasus meningitis bakteri 56\% laki-laki dengan rerata usia 15 bulan. Pada penelitian ini, pada kelompok curiga meningitis $51,6 \%$ adalah laki-laki, sedangkan pada kelompok dengan meningitis bakteri didapatkan perbandingan laki-laki dengan perempuan 3:1.

Pada penelitian kami, kecurigaan meningitis terbanyak pada usia 1-5 tahun, sedangkan meningitis bakteri paling banyak terjadi pada usia kurang dari 1 tahun. Hal tersebut sesuai dengan penelitian Owusu ${ }^{12} \mathrm{di}$ Ghana. Perbedaan usia dan jenis kelamin kemungkinan karena perbedaan mekanisme penyakit dan kekebalan tubuh pejamu melawan organisme penyebab. ${ }^{13}$

Kejang pada kasus meningitis bakteri terjadi pada sepertiga kasus, ${ }^{14}$ terutama pada kasus yang disebabkan oleh S. pneumonia, N.meningitidis, dan H. influenza. Kami mendapatkan kejang pada kelompok dengan curiga meningitis adalah 29/31, lebih tinggi dari penelitian sebelumnya kemungkinan karena kuman penyebabnya berbeda dan kejang sangat dipengaruhi oleh faktor genetik dan usia. Kejang merupakan salah satu indikator pada meningitis bakteri dengan sensitivitas 59\%, spesifisitas 94\%. ${ }^{15}$ Setelah dilakukan analisis bivariat, didapatkan adanya riwayat kejang saja tidak memiliki hubungan terhadap kejadian meningitis bakteri.

Pada anak, gejala iritasi meningeal seperti neck stiffness, reflex, Brudzinski reflex, dan Kernig sign atau tripod phenomenon tidak spesifik untuk meningitis bakteri. Iritasi meningeal hanya terjadi pada sepertiga kasus. ${ }^{16}$ Hal tersebut sesuai dengan penelitian kami yang mendapatkan tanda meningeal pada kelompok curiga meningitis $17 / 31$ dan pada kelompok meningitis bakteri adalah 8/12. Pasien curiga meningitis 15/31 datang dengan penurunan kesadaran. Sama dengan penelitian Karanika $\mathrm{dkk}^{17}$ yang menemukan penurunan kesadaran hanya terjadi pada $70 \%$ kasus meningitis bakteri.

Insiden meningitis bakteri bervariasi di seluruh dunia. ${ }^{18}$ Beberapa bakteri merupakan patogen meningitis bakteri, antara lain group B Streptococcus, Salmonella spp, Streptococcus spp, Pseudomonas aeruginosa, Escherichia coli, Staphylococcus spp, Brucella melitensis, Klebsiella pneumoniae, Acinetobacter anitratus, Enterobacter cloaca, mycoplasma pneumoniae, Proteus spp and Rickettsiae spp. ${ }^{17}$

Kami mendapatkan kultur positif $12 / 31$ pasien dengan hasil terbanyak Paeruginosa. Hal tersebut berbeda dengan beberapa penelitian di negara lain. Farag $\mathrm{dkk}^{19}$ menunjukkan penyebab meningitis bakteri terbanyak $H$. influenza, N.meningitidis dan S.pneumonia. Demikian juga dengan penelitian Karanika dkk, ${ }^{17}$ di Africa, Dubos dkk, ${ }^{2}$ di Francis, dan Berkley dkk, ${ }^{15}$ di Kenyan. Namun, penelitian Khan $\mathrm{dkk},{ }^{21}$ di India mendapatkan S. Aureus dan Pseudomonas sp merupakan bakteri patogen yang predominan pada kasus meningitis nosokomial. Hal tersebut sama dengan penelitian kami.

Beberapa faktor yang mungkin menyebabkan perbedaan jenis bakteri pada biakan antara lain 
kemampuan dari laboratorium masing-masing fasilitas kesehatan. ${ }^{22}$ Teknik biakan yang kami gunakan telah disesuaikan untuk kuman-kuman tersebut, yaitu penggunaan agar darah dan agar coklat. Pengecatan langsung dengan gram didapatkan adanya beberapa kuman dalam satu sampel, adanya kuman Diplococcus pada pengecatan langsung yang mungkin N.meningitidis, tetapi tidak tumbuh dalam biakan.

Faktor lain yang memengaruhi kultur LCS antara lain penggunaan antibiotik sebelum kultur dilakukan dan adanya enzim autolisis pada LCS. ${ }^{7}$ Pada penelitian kami, eksklusi hanya pada pasien yang telah mendapat terapi antibiotik dosis intrakranial 72 jam sebelumnya. Faktor lain adalah jumlah koloni bakteri. Jumlah koloni $10^{6}$ unit/mL di LCS akan menunjukkan 70\%$80 \%$ positif pada pengecatan gram. ${ }^{14}$ Penelitian kami tidak menggunakan perasat lain untuk memastikan adanya jenis bakteri tertentu dalam LCS, misalnya dengan aglutinasi latex atau $P C R$

Salah satu faktor lain yang menyebabkan rendahnya isolasi kuman pada LCS karena terutama pasien merupakan pasien rujukan dari daerah yang sebelumnya telah mendapat terapi. ${ }^{21}$ Demikian juga halnya penelitian kami, mengingat RSUP Dr. Sardjito merupakan pusat rujukan dari daerah sekitarnya. Hanya saja dalam penelitian kami tidak terdapat data mengenai hal itu.

Meningitis yang didapat dari rumah sakit (meningitis nosokomial) biasanya disebabkan Staphylococcus, bakteri Gram negatif, dan jamur. ${ }^{11}$ Staphylococcus adalah patogen yang paling umum untuk kasus meningitis nosokomial. S.epidermidis dan Enterococcus merupakan bakteri Gram positif, koagulase negatif, dan bagian dari flora normal manusia. S. epidermidis pernah dilaporkan dapat menyebabkan meningitis terutama pada anak dengan imunocompromised, demikian juga dengan Bacillus, sp. dan S. epidermidis juga merupakan devise-related meningitis antara lain akibat pemasangan shunt LCS. ${ }^{14,21}$

Suatu alat diagnosis yang baik, idealnya memiliki sensitivitas dan spesifisitas yang cukup tinggi untuk menyingkirkan kemungkinan negatif atau positif semu. ${ }^{23}$ Pada penelitian kami, nilai sensitivitas yang didapatkan lebih rendah dibandingkan dengan penelitian sebelumnya. Perbedaan nilai sensitivitas yang didapat dengan penelitian sebelumnya kemungkinan karena jumlah sampel yang lebih sedikit. Kriteria pemilihan sampel juga berbeda. Pasien penelitian kami dengan suspected meningitis akut berdasarkan kriteria WHO, sementara penelitian sebelumnya berdasarkan adanya pleositosis pada LCS, sedangkan untuk spesifisitas lebih baik dari penelitian sebelumnya. Keperluan skrining diperlukan alat dengan sensitivitas yang sangat tinggi untuk mencari penyakit pada subyek yang asimtomatis walaupun spesifisitasnya sedikit rendah. ${ }^{23}$ Dalam hal ini, untuk skrining, $B M S$ dapat juga digunakan dengan nilai sensitivitas 83,3\%. Dibandingkan dengan indikator yang lain, $B M S$ memiliki nilai sensitivitas yang paling tinggi.

Beberapa kelemahan penelitian kami antara lain adalah tidak dilakukan uji kappa untuk kesesuaian pengukuran. Selain itu, dari hasil pengamatan masih didapatkan kemungkinan adanya kontaminasi kuman dalam proses pengambilan LCS. Kami juga tidak menggunakan perasat diagnostik lain yang dapat membantu menegakkan diagnosis meningitis bakteri dan memastikan tidak adanya penyebab infeksi selain bakteri misalnya virus. Selain itu, jumlah sampel yang digunakan pada penelitian sedikit dengan hanya menggunakan presisi $80 \%$.

\section{Kesimpulan}

Bacterial meningeal score merupakan indikator yang baik untuk menilai meningitis bakteri pada bayi dan anak karena memiliki sensitivitas, spesifisitas, nilai praduga negatif, nilai praduga positif, likelihood ratio positif dan likelihood ratio negatif yang tinggi.

\section{Daftar pustaka}

1. Maria B, Bale JF. Infection of nervous system. Dalam: Menkes J, Sanart H, Maria B, penyunting. Child Neurology. Edisi ke-7. California: Lippincott Williams \& Wilkins; 2006. h. 434-55.

2. Dubos F, De la Rocque F, Levy C, Bingen E, Aujard Y, Cohen R, dkk. Sensitivity of the bacterial meningitis score in 889 children with bacterial meningitis. J Pediatr 2008;152:378-82.

3. Nigrovic LE, Kuppermann N, Malley R. Children with bacterial meningitis presenting to the emergency department during the pneumococcal conjugate vaccine era. Acad Emerg Med 2008;15:522-8.

4. Nigrovic LE, Kuppermann N, alley R. Development and validation of a multivariable predictive model to distinguish bacterial from aseptic meningitis in children 
in the post- Haemophilus influenzae era. Pediatrics 2002;110:712-9.

5. Nigrovic LE, Kuppermann N, Macias CG, Cannavino CR, Moro-Sutherland DM, Schremmer RD, dkk. Clinical prediction rule for identifying children with cerebrospinal fluid pleocytosis at very low risk of bacterial meningitis. JAMA 2007;297:52-60.

6. Nigrovic LE, Malley R, Agrawal D, Kuppermann N. Low risk of bacterial meningitis in children with a positive enteroviral polymerase chain reaction test result. Clin Infect Dis 2010;51:1221-2.

7. Mani R, Pradhan S, Nagarathna S, Wasiulla R, Chandramuki A. Bacteriological profile of communitty acquires acute bacterial meningitis: a ten retrospective study in a tertiary nedurocare centre in South India. Indian J. Clin Microbiol 2007;25:108-14.

8. Roca A, Bassat Q, Morais L, Machevo S, Sigauque B, O'Callaghan C, dkk. Surveillance of acute bacterial meningitis among children admitted to a district hospital in rural Mozambique. Clin Infect Dis 2009;48 Suppl 2:S172-S180.

9. El-Nawawy AA, Abd El-Fattah MM, Metwally HA, Barakat SS, Hassan IA. One year study of bacterial and fungal nosocomial infections among patients in pediatric intensive care unit (PICU) in Alexandria. J Trop Pediatr 2006;52:185-91.

10. Saharso D, Hidayati S. Infeksi susunan syaraf pusat. Dalam: Soetomenggolo T, Ismael S, penyunting. Neurologi Anak.Jakarta: Ikatan Dokter Anak Indonesia; 1999. h. 339-62.

11. Roca J, Campos J, Monso G, Trujillo G, Riverola A, Suris JC. Meningitis in pediatrics. Clinical and epidemiological study of 173 cases. Enferm Infecc Microbiol Clin 1992;10:79-88.

12. Owusu M, Boaitey YA, Badu-Boateng E, Adu-Sarkodie Y, Nguah S.M, Abubakr A, dkk. Aetiological agents of cerebrospinal meningitis: a retrospective study from a teaching hospital in Ghana. Annals of Clinical Microbiology and Antimicrobials 2012;1-8.

13. van Driel JJ, Bekker V, Spanjaard L, van der Ende
A, Kuijpers TW. Epidemiologic and microbiologic characteristics of recurrent bacterial and fungal meningitis in The Netherlands, 1988-2005. Clinical Infectious Diseases 2008;47:e42-e51.

14. Saez-Llorens X, McCracken GH. Bacterial meningitis in children. Lancet 2003;361:2139-48.

15. Berkley JA, Versteeg AV, Mwangi I, Lowe BS, Newton $\mathrm{C}$, Charles RJ. Indicators of acute bacterial meningitis in children at a rural kenyan district hospital. Pediatrics 2004;114:e713-e9.

16. Chavez-Bueno S, McCracken GH, Jr. Bacterial meningitis in children. Pediatr Clin North Am 2005;52:795810.

17. Karanika M, Vasilopoulou VA, Katsioulis AT, Papastergiou P, Theodoridou MN, Hadjichristodoulou CS. Diagnostic clinical and laboratory findings in response to predetermining bacterial pathogen: data from the meningitis registry. PLoS ONE 2009;4:e6426.

18. Aslam M, Hafeez A, Tahir M. Bacterial meningitis: a diagnostic approach. Biomedica 2006;22:96-7.

19. Faraq H, Abdel Fatah M, Youssri M. Epidemiological, clinical and prognostic profile of acute bacterial meningitis among children in Alexandria, Egypt. Indian J Clin Microbiol 2005;23:95-101.

20. Dubos F, Moulin F, Gendrel D, Breart G, Chalumeau M. Distinguishing between bacterial and aseptic meningitis in children in the emergency department. Arch Pediatr 2008;15:724-5.

21. Khan F, Rizvi M, Fatima N, Shukla I, Malik A, Khatoon R. Bacterial meningitis in North India: trends over a period of eight years. Neurolgy Asia 2011;16:47-56.

22. Muangchana C, Chunsuttiwat S, Rerks-Ngarm S, Kunasol P. Bacterial meningitis incidence in Thai children estimated by a rapid assesment tool (RAT). South Asian J Trop Med Public Health 2009;40:553-61.

23. Pusponegoro HD, Wirya IGN.W, Pudjiadi A.H, Bisanto J, Zulkarnain SZ. Uji diagnostik. Dalam: Sastroasmoro S, Ismael $S$, penyunting. Dasar-dasar metodologi penelitian klinis. Edisi ke-4. Jakarta: Sagung Seto; 2011.h.119239. 